\title{
Effect of Calcination Temperature on the Pozzolanic Activity of Brazilian Sugar Cane Bagasse Ash (SCBA)
}

\author{
Daniel Véras Ribeiro ${ }^{\mathrm{a} *}$, Marcio Raymundo Morelli ${ }^{\mathrm{b}}$ \\ ${ }^{\mathrm{a}}$ Department of Materials Science and Technology, Federal University of Bahia - UFBA, \\ Rua Aristides Novis, 02, Federação, CEP 40210-630, Salvador, BA, Brazil \\ ${ }^{\mathrm{b}}$ Department of Materials Engineering, Federal University of São Carlos - UFSCar, \\ Rodovia Washington Luis, Km 235, CEP 13566-550, São Carlos, SP, Brazil
}

Received: December 25, 2013; Revised: April 17, 2014

\begin{abstract}
This study evaluated the feasibility of using sugar cane bagasse ash (SCBA), a by-product of the sugar cane ethanol industry, obtained under controlled calcination as a partial replacement for Portland cement in mortars. Materials with pozzolanic characteristics may be used to partially replace cement in mortars or concrete and are known to provide durability to the products. Initially, TG/DTA curves of the sugar cane bagasse were conducted to define suitable calcination temperatures $\left(500^{\circ} \mathrm{C}, 600^{\circ} \mathrm{C}\right.$ and $700^{\circ} \mathrm{C}$ ), and tests were conducted to characterize the physical-chemical parameters of the SCBA and the pozzolanic activity according to NP EN 196-5. The results showed the technical feasibility of using the SCBA as a pozzolanic material in construction, which would provide an alternative to proper disposal for this waste while providing products with high technical performance.
\end{abstract}

Keywords: sugar cane bagasse ash - SCBA, mortar, pozzolanic activity, SCM

\section{Introduction}

Sugar cane is one of the most significant products of the Brazilian economy. Brazil has become the largest producer of not only sugar cane but also sugar and ethanol made from sugar cane. This ethanol is gaining popularity on the international market with the growing demand for new clean energy alternatives. Due to this demand, the sugar cane ethanol industry will continue to grow in the coming years, causing an increase in waste generated by this industry. This waste has the potential to cause serious environmental problems if it is improperly disposed.

Historically, sugar cane is one of the main products of Brazilian agriculture. It has been cultivated since the era of Portuguese colonization and emerged in the eighteenth century when sugar became the main export of the country. Currently, Brazil is the leading producer of sugar cane and the source of over half of the sugar traded in the world. The average rate of increase in annual production expected until $2018-2019$ is $3.25 \%{ }^{1}$.

Bagasse is a residue that is generated by the sugar cane processing to obtain the final product (sugar or ethanol). Much of this bagasse is burned in boilers in a co-generation power process. This process has the potential to make some industries energy self-sufficient, and could provide the possibility of selling surplus power. The process of burning bagasse generates sugar cane bagasse ash (SCBA), which is a major final waste from the sugar cane industry. The amount of bagasse produced annually in Brazil represents approximately $30 \mathrm{wt} \%$ of the sugar cane processed in plants ${ }^{2}$, assuming an ash yield of $10 \mathrm{wt} \%$ after calcination ${ }^{3}$.

\footnotetext{
*e-mail: verasribeiro@ hotmail.com
}

Today, Portland cement is the most widely used building material in the world. The worldwide use of this material is expected to continue to grow because this material offers desirable properties at a low cost ${ }^{4}$. The world production of Portland cement is approximately 3.3 billion tons (2010) and has shown steady growth in recent years ${ }^{5}$. The utilization of solid wastes as mineral admixtures to partially replace cement could preserve the non-renewable resources that are required for the production of cement and could therefore contribute to sustainable concrete construction. Hence, the inclusion of SCBA in concrete could serve as an effective means of its disposal.

The use of supplementary cementitious materials (SCMs), such as fly ash, ground granulated blast-furnace slag, silica fume, red mud and metakaolin, as part of binders for concrete has been increasing throughout the world, particularly in the production of high-strength and highperformance concrete. This replacement is possible because of the potential ability of these materials to enhance the properties and performance of concrete through their filler effect and through the pozzolanic reaction ${ }^{6-9}$.

According to Johari et al. ${ }^{7}$, different types of materials used as partial cement replacement materials or as mineral additives can have different effects on the properties of cementitious matrices due their different chemical and mineralogical compositions, as well as different particle characteristics, which determine their water requirement, packing ability, and their reactivity when used as part of a binder for concrete. In general, the use of these materials in concrete has been associated with the refinement of the concrete pore structure. 
The pozzolanic activity of a material primarily depends on two factors: the amount of calcium hydroxide available for the reaction with the pozzolan and the reaction rate that this combination occurs. The amount of available calcium hydroxide depends on the chemical properties of the pozzolan used, the nature of its active phase, the content of $\mathrm{SiO}_{2}$ in the active pozzolan and the $\mathrm{Ca}(\mathrm{OH})_{2} /$ pozzolan ratio in the mixture. The reaction rate depends on physical factors, such as the surface area of pozzolan, the solid to water ratio of the mixture and the temperature.

The benefits of pozzolanic materials is due to their physical and chemical characteristics, such as their effects on particle packing and their ability to provide amorphous silica to react with $\mathrm{Ca}(\mathrm{OH})_{2}$ during the cement hydration reactions ${ }^{10}$. When amorphous silica comes into contact with water, it solubilizes into an alkaline solution and reacts with $\mathrm{Ca}^{+2}$ ions, forming hydrated calcium silicates similar to those produced through cement hydration reactions. Paula et al. $^{3}$ found that the composition of SCBA was approximately $84 \%$ silica. Similar values were also found by Lima et al. ${ }^{11}$ and Frías et al. ${ }^{12}$, who found silica composition percentages of $75 \%$ and $70 \%$, respectively. SCBA therefore has high levels of silica under normal conditions, and if suitable calcination parameters are used, such as controlled calcination temperatures, heating rate and burn time, it is possible to keep the silica in the amorphous state ${ }^{10}$.

Burning bagasse for energy generation produces ash as a final waste product. However, due to the absence of a pulp washing process prior to its use in industry, the waste obtained is often referred to as sugar cane bagasse $a^{11,13}$, which is actually a mixture of sand from cutting the cane and ash from burning bagasse. This waste, which is referred to as sugar cane bagasse ash sand (SCBAS) in this report, usually consists of a much larger amount of sand (approximately $98 \mathrm{wt} \%$ ), and a small amount of ash. Most of the waste collected from plants is sugar cane bagasse ash sand (SCBAS).

High-purity sugar cane bagasse ash (SCBA) is obtained by calcining the sugar cane bagasse after the sand that is mixed with the material has been washed away. Burning bagasse without sand forms a residue composed of only ash. This paper will evaluate the properties of this ash and how these properties change under different calcination scenarios.

Several studies have investigated the feasibility of using both types of waste in construction. Lima et al. ${ }^{11}$ used SCBAS in their studies and showed the feasibility of their use in the replacement of fine aggregate in mortars, while Nunes et al. ${ }^{13}$ has observed a gain of resistance in concrete when up to $13 \mathrm{wt} \%$ of Portland cement was replaced by SCBAS. Cordeiro et al. ${ }^{10}$ used sugar cane bagasse ash that was obtained after washing bagasse and verified the existence of pozzolanic properties, confirming the feasibility of its use as a partial replacement for Portland cement. Frías ${ }^{12}$ notes that even with cross-contamination by soil particles, ash obtained under controlled calcination conditions have higher pozzolanic activity than waste obtained directly from the production line of the sugar cane ethanol industry.

Materials with pozzolanic characteristics may be used to partially replace cement in mortars or concrete, and has been shown to increase the durability of products ${ }^{14,15}$. This study evaluates the pozzolanic activity of calcined sugarcanesugar cane bagasse ash (SCBA) in cementitious matrices and determines the best calcination temperature for its production.

\section{Material and Methods}

\subsection{Material}

The mortars were produced with Portland cement type CP V - ARI. The fine aggregate used was natural siliceous sand. The sugar bagasse was supplied by União Industrial Açucareira Ltda. from Amélia Rodrigues, Bahia, Brazil.

The waste from the production of sugar and ethanol is usually stored outdoors (Figure 1a). Figure 1b shows a sample of bagasse, in natura. The sugar cane bagasse ash (SCBA) used in this study was obtained by calcining the sugar cane bagasse after it was subjected to a washing process to remove the sand grains mixed with the product.

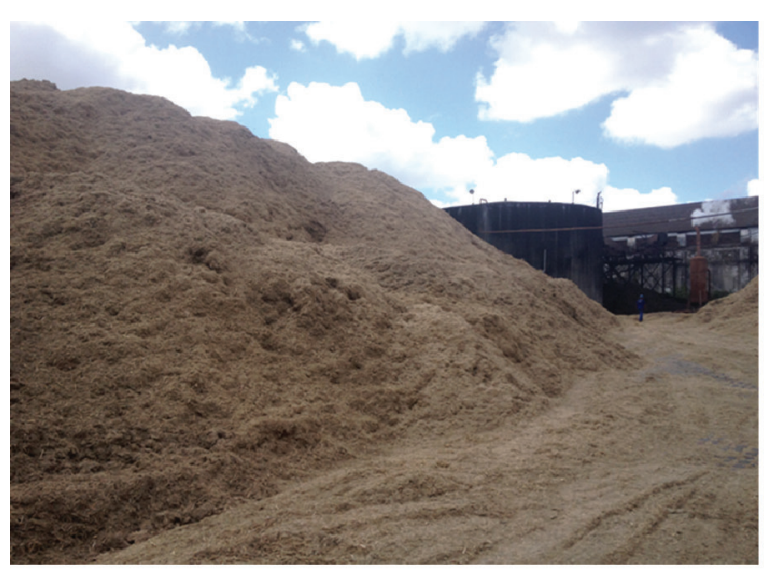

(a)

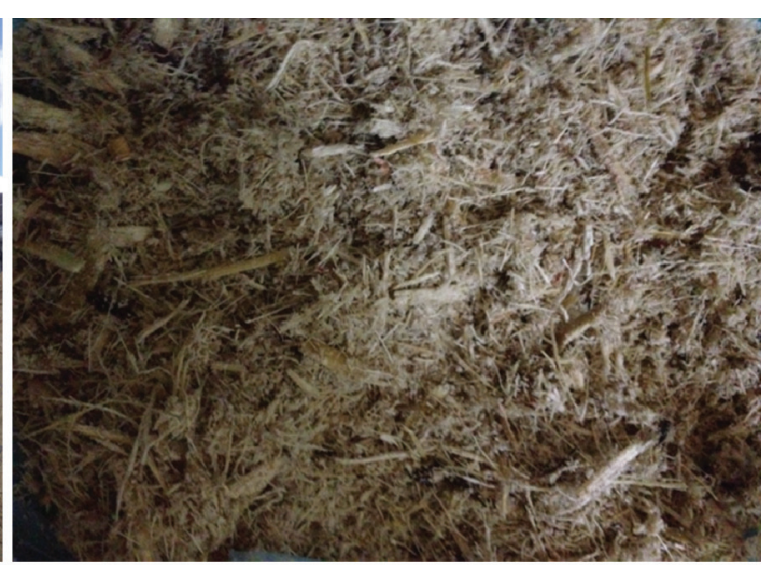

(b)

Figure 1. (a) Storage of bagasse on União Industrial Açucareira Company; and (b) Sugar cane bagasse ash sample, in natura. 


\subsection{Methods}

\subsubsection{Materials characterization}

The sugar cane bagasse ash (SCBA) was characterized by X-ray diffraction (Rigaku Geirgeflex ME 210GF2 Diffractometer, configured with $\mathrm{CuK} \alpha$ radiation, $40 \mathrm{KV}$ voltage, $100 \mathrm{~mA}$ current, $2 \theta$ scanning and scanning speed $4 \%$ min). Relevant physical parameters, such as the specific surface area (estimated by BET using a Micrometrics Gemini 2370 V1.02) and specific gravity (estimated using a Helium Pycnometer Accupyc 1330 V2.01 from Micrometrics) were determined.

In addition to the physical characterization of sugar cane bagasse, the microstructural characterization was also performed using scanning electron microscopy (SEM). For this study, a thin gold coating layer was used, which served as a means of conducting electrons. The samples were analyzed in a Zeiss FEG scanning electron microscope containing an energy dispersive X-ray spectroscopy (EDS) detector. A $25 \mathrm{kV}$ voltage and $15 \mathrm{~mm}$ working distance were used.

TG analysis was carried out on a Labsys Setaram with dry $\mathrm{N}_{2}$ as the stripping gas to study the thermal behavior of the SCBA and to define the calcination conditions. The heating rate was $10^{\circ} \mathrm{C} / \mathrm{min}$, and the samples were heated from $20^{\circ} \mathrm{C}$ to $1100^{\circ} \mathrm{C}$.

\subsubsection{SCBA calcination}

The sugar cane bagasse ash (SCBA) was calcined using a Linn Elektro Therm oven with a heating rate of $10^{\circ} \mathrm{C} / \mathrm{min}$. Three distinct temperatures were selected (500, 600, and $700^{\circ} \mathrm{C}$ ) according to the $\mathrm{TG}$ results. The dwell time was fixed at 6 hours.

\subsubsection{Dosage and physical characterization of mortars}

The mortar formulation used as a reference was prepared in a 1.0:3.0:0.50 (cement:sand:water) weight ratio. Distinct mortars in which Portland cement was partially replaced by SCBA $(10 \mathrm{wt} \%)$ and calcined at different temperatures were analyzed.

After mixing, prismatic specimens $4 \times 4 \times 16 \mathrm{~cm}^{3}$ in size were molded and left for 24 hours, after which they were immersed in water and placed in a climatic chamber at $38 \pm 2{ }^{\circ} \mathrm{C}$ with $60 \%$ relative moisture for 28 days. After this curing period, five specimens of each composition were selected, and the flexural and axial compressive strength was evaluated.

The values of axial compression and flexural strength were determined as the average of the five values for each composition and mortar age (3, 7 and 28 days after molding) and were obtained with a CONTENCO 120-T testing machine at a load of $1.5 \mathrm{~mm} / \mathrm{min}$. The values that differed by more than $5 \%$ from the average were discarded and replaced by the results of new tested samples.

\subsubsection{Pozzolanic activity}

The pozzolanic activity of the SCBA was evaluated by determining the physical and chemical parameters of the mixtures. The physical determination follows the NBR 13279 Brazilian standard ("Mortars applied on walls and ceilings - Determination of the flexural and the compressive strength in the hardened stage"). The water to binder (cement + pozzolan) and binder to aggregate ratios were kept constant and were equal to 0.5 and 3.0, respectively. However, the water to cement ratio was higher (0.56) for mixtures containing $10 \mathrm{wt} \%$ SCBA.

The pozzolanic characteristic of the SCBA was evaluated by chemical tests according to NP EN 196-5. According to this standard, the pozzolanic index is determined by comparing the amount of calcium hydroxide present in the aqueous solution that contacts with the hydrated sample after a defined period of time to the amount of calcium hydroxide required to saturate the environment with a similar alkalinity. The test is considered positive if the calcium hydroxide concentration in solution is lower than the saturation concentration.

A mixture of $20 \mathrm{~g}$ cement to $100 \mathrm{ml}$ distilled water was used as the standard. The SCBA mixture evaluated contained $15 \mathrm{~g}$ cement and $5 \mathrm{~g}$ SCBA per $100 \mathrm{ml}$ distilled water. Two replicas for each test were left in a climate chamber at $40 \pm 2^{\circ} \mathrm{C}$ and a relative humidity of $60 \%$ for 14 days.

\section{Results and Discussion}

\subsection{Materials characterization}

The Portland cement (CP V-ARI) used in this study had a specific surface area of $0.8924 \mathrm{~m}^{2} / \mathrm{g}$ and a specific gravity of $3.17 \mathrm{~kg} / \mathrm{dm}^{3}$. The sand had a specific surface area of $0.012 \mathrm{~m}^{2} / \mathrm{g}$ and a specific gravity of $2.60 \mathrm{~kg} / \mathrm{dm}^{3}$.

The received sugar cane bagasse contained approximately $70 \%$ sand (Figure 1b). The bagasse was washed to remove the sand, dried and calcined to form a powdered additive. The morphology of sugar cane bagasse is illustrated in Figure 2. The composition of the bagasse was mainly composed of carbon and silicium, according to the EDS analysis.

TG/DTA curves of the sugar cane bagasse are presented in Figure 3 and were conducted to determine suitable calcination temperatures.

For temperatures up to $480^{\circ} \mathrm{C}$, the material showed a continuous weight loss, reaching approximately $77 \%$. This result suggests that the occurrence of decomposition reactions, such as those involving the removal of adsorbed water and organic matter. Weight loss was not observed at temperatures above $480^{\circ} \mathrm{C}$, suggesting that the decomposition reactions were complete.

Thus, based on the results of TG shown in Figure 3, calcination temperatures were chosen as $500^{\circ} \mathrm{C}, 600^{\circ} \mathrm{C}$ and $700^{\circ} \mathrm{C}$. The ashes resulting from exposure to these temperatures were mineralogically analyzed by XRD (Figure 4).

According to Figure 4, an increase of the amorphous character of ash can be visualized (XRD background, where the hump is caused by the present amorphous, nondiffracting, component) primarily by the alpha phase silica $\left(\mathrm{SiO}_{2}\right)$ and the formation of calcium silicate and calcium aluminate phases, neither of which were observed at $500^{\circ} \mathrm{C}$. Thus, it is observed that the reactivity of the ashes increases when the calcination temperature is increased and stabilizes 

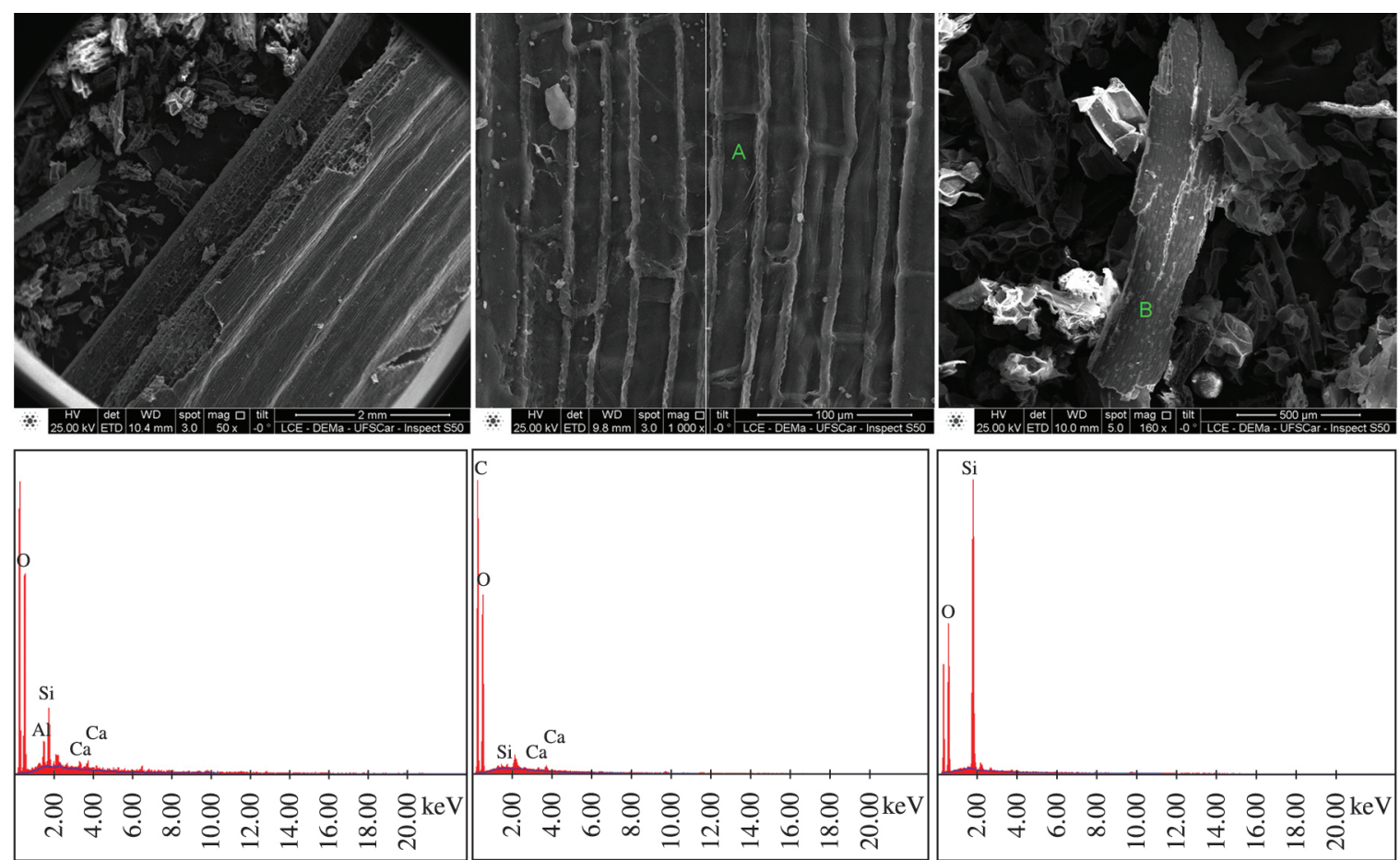

(a)

(b)

(c)

Figure 2. SEM micrographs and EDS of sugar cane bagasse after washing.

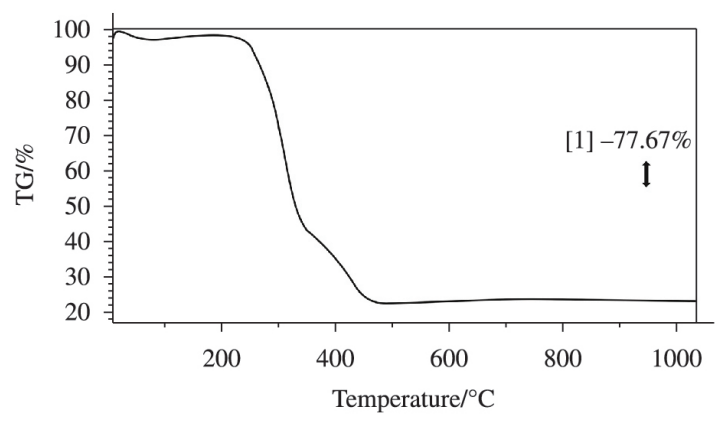

Figure 3. TG curve of the sugar cane bagasse.

after $600^{\circ} \mathrm{C}$, which is in agreement with the results observed in the TG curve (Figure 3).

Cordeiro et al. ${ }^{10,16}$ showed that burning ashes between $400^{\circ} \mathrm{C}$ and $600^{\circ} \mathrm{C}$ produces an increase in the pozzolanic activity index with increasing firing temperatures due to the loss of carbon during the calcination process. According to these authors, the formation of crystalline silica compounds is observed at a firing temperature of $800^{\circ} \mathrm{C}$, causing a drop in the pozzolanic activity index at that temperature. These authors suggest that the optimal temperature for the production of pozzolanic SCBA is $600^{\circ} \mathrm{C}$ because at this temperature it is possible to generate predominantly amorphous silica with a pozzolanic activity index of $77 \%$

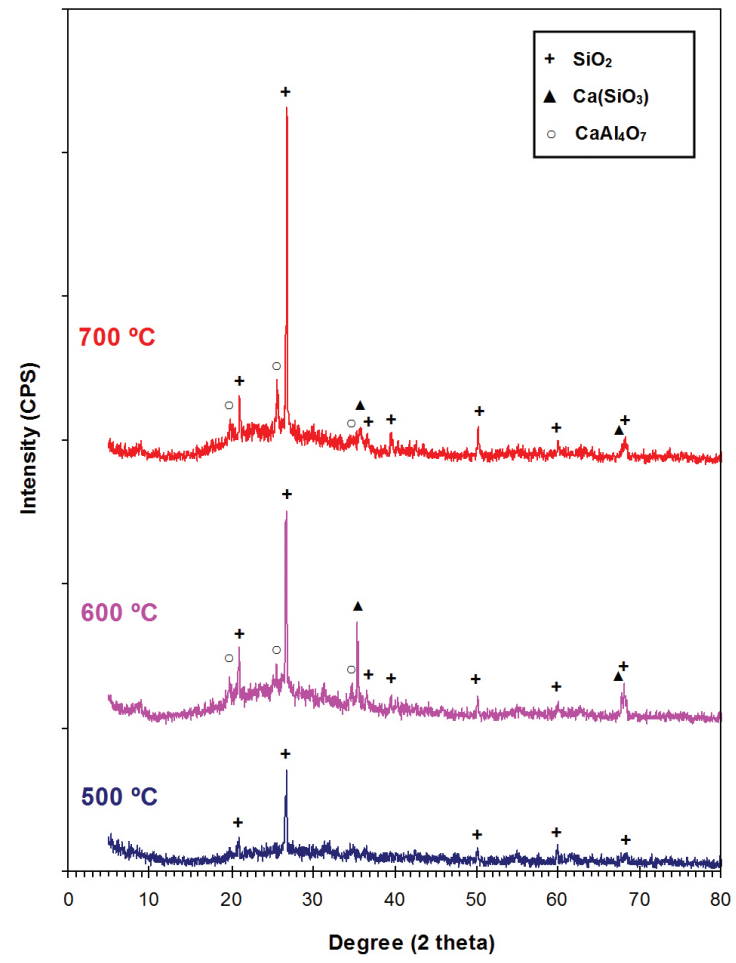

Figure 4. X-ray diffraction patterns of the sugar cane bagasse ash obtained after calcination at 500,600 and $700^{\circ} \mathrm{C}$. 
Table 1. Effect of the calcination temperature on the main physical properties of SBCA.

\begin{tabular}{cccc}
\hline Calcination Temperature & $\begin{array}{c}\text { Specific surface area BET } \\
\left(\mathbf{m}^{2} / \mathbf{g}\right)\end{array}$ & Specific gravity $\left(\mathbf{g} / \mathbf{c m}^{3}\right)$ & Unitary mass $\left(\mathbf{g} / \mathbf{c m}^{3}\right)$ \\
\hline $500^{\circ} \mathrm{C}$ & 32.9708 & 4.19 & 0.055 \\
$600^{\circ} \mathrm{C}$ & 32.3502 & 3.17 & 0.089 \\
$700^{\circ} \mathrm{C}$ & 31.6265 & 3.24 & 0.090 \\
\hline
\end{tabular}

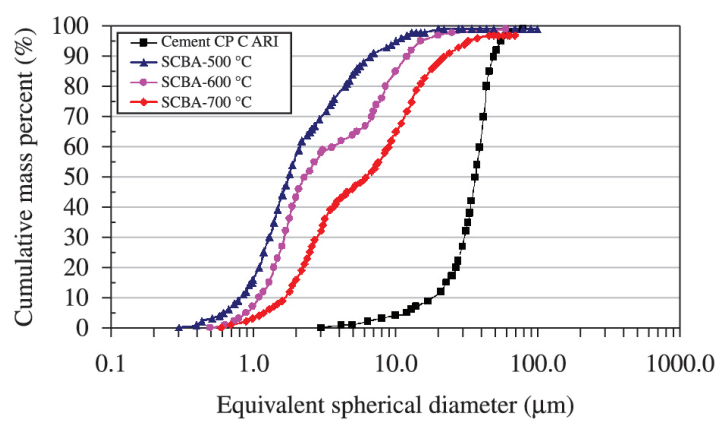

Figure 5. Particle size distribution of the cement and the SCBA after calcination at 500,600 and $700^{\circ} \mathrm{C}$. and a loss of ignition of $5.7 \%$ when accounting for the NBR 12653 Brazilian standard determinations ("Pozzolanic Materials - Requirements").

Other researchers ${ }^{3,13}$ have shown that it is feasible to replace up to $20 \%$ of Portland cement (OPC) by SCBA, producing higher resistance values in replacement levels up to $15 \%$. Paula et al. ${ }^{3}$ noted that for a calcination temperature of $600^{\circ} \mathrm{C}$ for a period of 6 hours, it is possible to obtain ash with $\mathrm{SiO}_{2}$ content $84 \mathrm{wt} \%$, both in the crystalline phase as in the amorphous phase and that it is possible to replace OPC with ashes up to $20 \mathrm{wt} \%$.

Calcination also changes some physical characteristics of the powder that might affect its reactivity. The values for
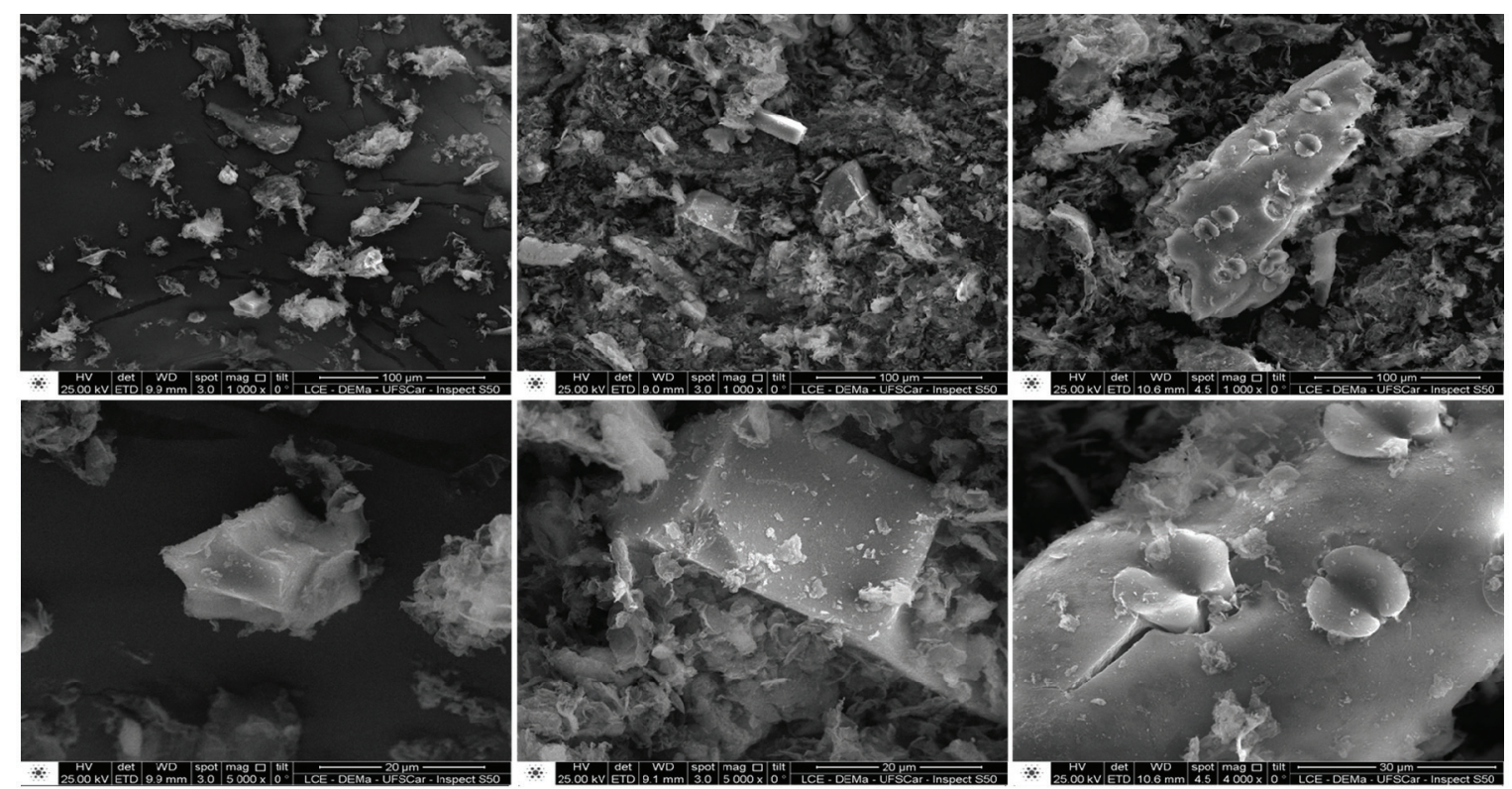

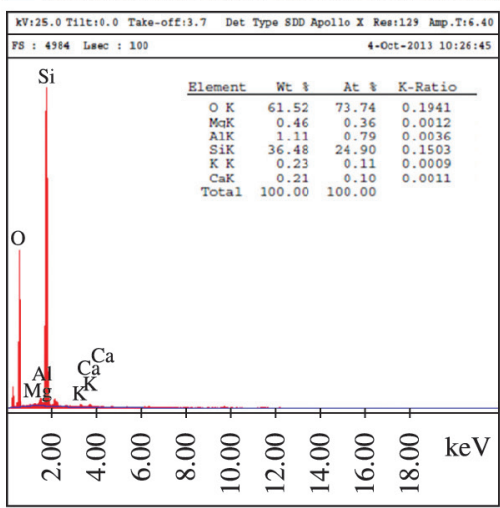

(a)

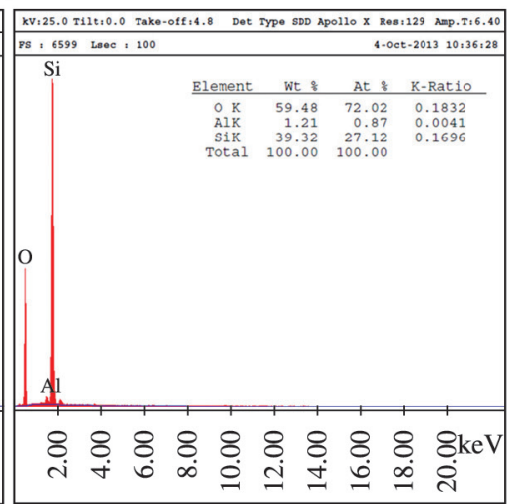

(b)

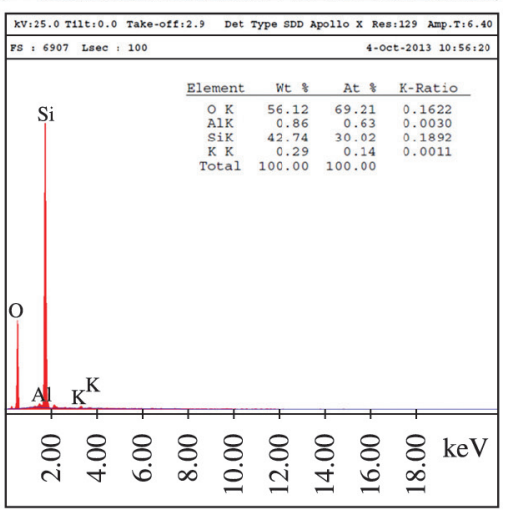

(c)

Figure 6. SEM micrographs and EDS of sugar cane bagasse ash (SCBA) after calcination at (a) $500^{\circ} \mathrm{C}$, (b) $600^{\circ} \mathrm{C}$ and (c) $700^{\circ} \mathrm{C}$. 
specific surface area, specific gravity and unit weight are given in Table 1. The evolution of grain size distribution is shown in Figure 5.

Increasing the calcination temperature tends to reduce the powder's density due to organic matter and water removal, and the grain size tends to increase as a result of the combination of components. However, the surface area of each powder remained almost unchanged.

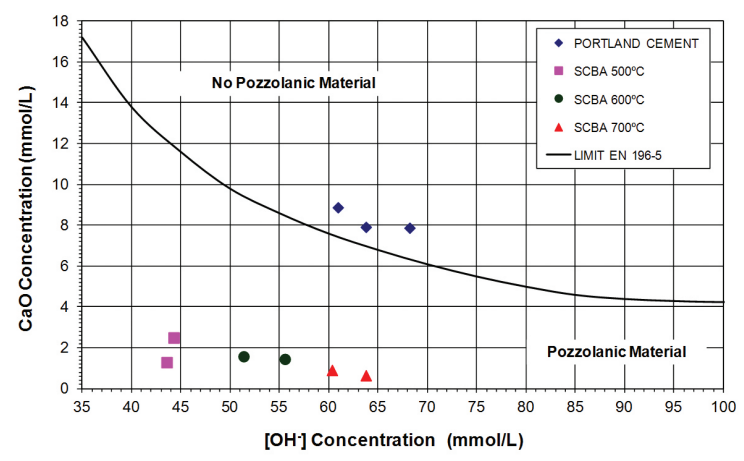

Figure 7. Diagram for determining the SCBA pozzolanicity according to the NP EN 196-5 standard.

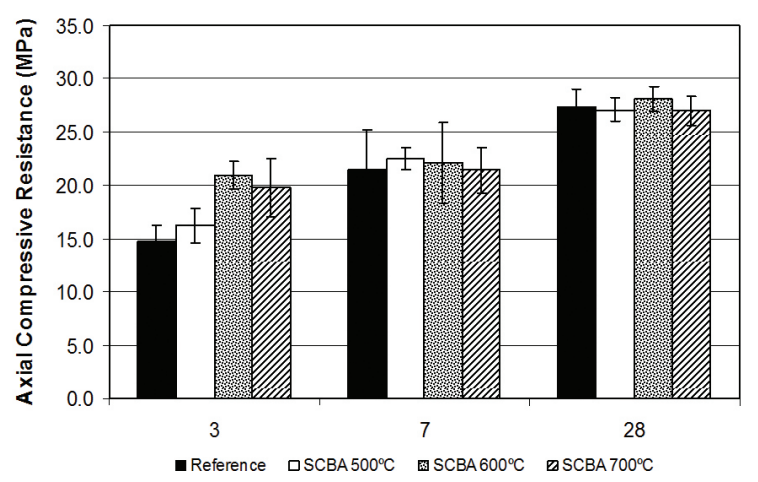

Age (days)
Changes in the SCBA morphology from differing calcination temperatures can be seen in Figure 6. According to $\mathrm{XRD}$ results, the ash obtained at $600^{\circ} \mathrm{C}$ has a higher amorphous character, which is confirmed in the SEM images (Figure 6b) and shows a tangled phase without a well-defined format.

\subsection{Verification of pozzolanic activity by chemical test method}

European Standard NP EN 196-5 compares the quantity of calcium hydroxide present in the aqueous solution in contact with cement hydrated after 14 days to the amount of calcium hydroxide required to saturate the environment of equal alkalinity. A material is considered pozzolanic if the calcium hydroxide concentration in solution is lower than the saturation concentration. These results are shown in Figure 7.

The pozzolanic effect is denoted by a decrease in $\mathrm{CaO}$ concentration in the liquid phase because calcium hydroxide generated through cement hydration is sequestered and combined by the pozzolan. As shown in Figure 7, the reference Portland cement does not qualify as a pozzolanic material because the cement alone is not pozzolanic. It is

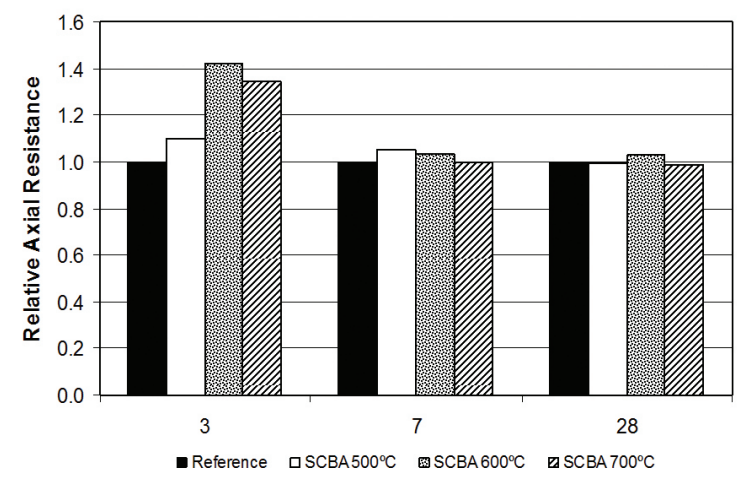

Age (days)

Figure 8. Axial compressive strength of mortars in which Portland cement was partially replaced by SCBA (10 wt $\%)$ and calcined at different temperatures.

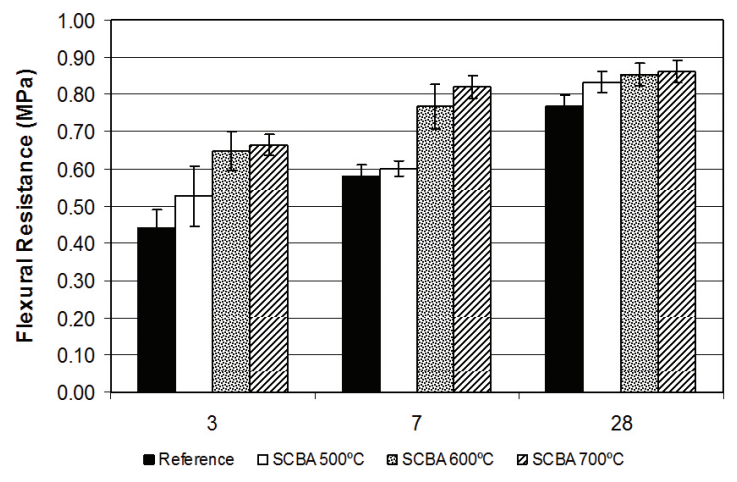

Age (days)

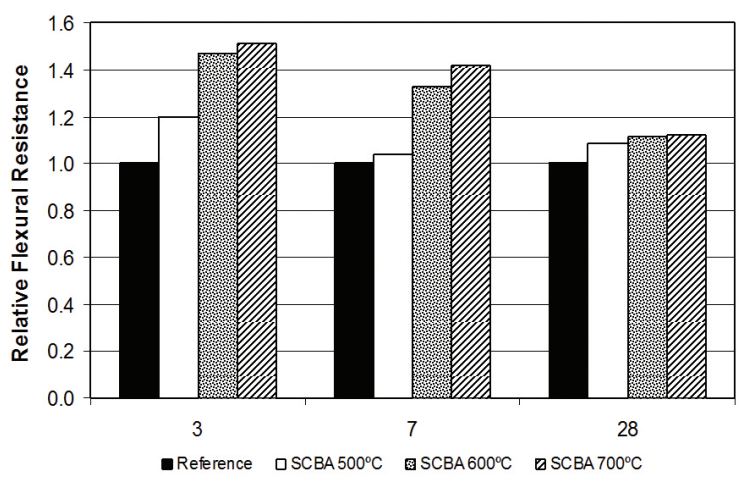

Age (days)

Figure 9. Flexural strength of mortars in which Portland cement was partially replaced by SCBA (10 wt \%) and calcined at different temperatures. 
the addition of the pozzolan in the presence of water that binds the calcium hydroxide that is formed by the cement hydration and lowers the calcium oxide content of the liquid phase of the cement paste pe, $^{8,17}$.

The $\mathrm{CaO}$ and $\mathrm{OH}^{-}$ion concentrations decrease in the solution when SCBA is added, and a clear pozzolanic action is observed for mixtures containing SCBA independent of the calcination temperature of the ash. It is generally accepted that the activity of the cementitious mineral mainly depends on its active $\mathrm{SiO}_{2}$ and $\mathrm{Al}_{2} \mathrm{O}_{3}$ content. Thus, the amount of dissolved $\mathrm{SiO}_{2}$ and $\mathrm{Al}_{2} \mathrm{O}_{3}$ in the $\mathrm{NaOH}$ solution can be used to evaluate the activity of the cement ${ }^{6}$.

\subsection{Verification of pozzolanic activity by physical test method}

Mechanical properties are holistic indicators of the microstructure development of cement matrices upon hydration. In addition to the chemical effects, values are mainly controlled by physical parameters such as porosity and compactness. The grain size distribution of components and the water to binder ratio are relevant parameters that control the workability of the mixtures in its fresh state and also affect the mechanical strength of the hardened bodies. Hence, the effect of a single component, such as the SBCA, is difficult to evaluate by only evaluating the mechanical strength of the mortar.

The comparisons of the mechanical test results are presented in Figures 8 and 9. The results show that the use of SBCA generates mixtures that have acceptable values of axial compressive strength in all situations. Optimal behavior is achieved by the use of SBCA calcined at $600^{\circ} \mathrm{C}$.

The compressive strengths of mortars are presented in Figure 8 . The specimens that ruptured after 3 days showed an increase in resistance in relation to the reference, which is also observed at 7 and 28 days, although the increase is less pronounced. The results of the flexural strength (Figure 9) confirm the behavior observed in axial compression,

\section{References}

1. Brasil. Ministério da Cultura, Pecuária e Abastecimento. Canade-açúcar. Brasília: MAPA; 2012. Available from: <http:// www.agricultura.gov.br/>. Access in: 10/10/2013.

2. Companhia Nacional de Abastecimento. Acompanhamento da safra brasileira: cana-de-açúcar. Terceiro Levantamento, dezembro/2012. Brasília: CONAB; 2012. Available from: $<$ http://www.conab.gov.br>. Access in: 10/10/2013.

3. Paula MO, Tinôco IFF, Rodrigues CS, Silva EN and Souza CF. Potencial da cinza do bagaço de cana-de-açúcar como material de substituição parcial de cimento Portland. Revista Brasileira de Engenharia Agrícola e Ambiental. 2009; 13(3):353-357. http://dx.doi.org/10.1590/S1415-43662009000300019

4. Ribeiro DV. Influência da adição da lama vermelha nas propriedades e na corrosibilidade do concreto armado. [Tese]. São Carlos: Universidade Federal de São Carlos; 2010.

5. Cimento.Org. Produção, consumo e comércio mundial. Cimento.Org; 2010. Available from: <http://www.cimento.org/ cimentomundo.htm>. Access in: 10/10/2013.

6. Dow $\mathrm{C}$ and Glasser FP. Alkali releases from crushed minerals and thermally activated constituents of metakaolin. Advances showing a trend of increased resistance at all ages examined. These results confirm the results of the chemical tests, suggesting the great technical potential of SCBA as a partial replacement for Portland cement.

According to Nunes et al. ${ }^{13}$, the pozzolanic reaction from the use of SCBA is extremely slow, especially when an efficient grinding process is not used. Thus, it is believed that studies using specimens aged for longer times will provide more satisfactory results.

\section{Conclusions}

Based on an analysis of the results, the following conclusions can be drawn:

- With increasing calcination temperatures of the sugar cane bagasse, there is an increase in the particle size of the resulting ash and a decrease in the specific gravity due to the loss of organic matter;

- The SCBA obtained from calcination temperatures of $500^{\circ} \mathrm{C}, 600^{\circ} \mathrm{C}$ and $700^{\circ} \mathrm{C}$ presented high pozzolanic activity as determined by the chemical test;

- According to the XRD results, the SCBA calcined at $600^{\circ} \mathrm{C}$ shows a higher amorphous character, which is illustrated by the greater reactivity of this material;

- The mortars prepared with a $10 \mathrm{wt} \%$ partial replacement of Portland cement by SCBA showed better mechanical properties compared to reference mortar for all temperatures examined, but particularly at calcination temperatures of $600^{\circ} \mathrm{C}$ and $700^{\circ} \mathrm{C}$;

- The calcined SCBA appears to be a promising partial substitution for Portland cement.

\section{Acknowledgements}

The authors wish to thank FAPESB - Bahia Research Foundation and $C N P q$ - National Counsel of Technological and Scientific Development (Brazil).

in Cement Research. 2003; 15(4):137-143. http://dx.doi. org/10.1680/adcr.2003.15.4.137

7. Megat Johari MA, Brooks JJ, Kabir S and Rivard P. Influence of supplementary cementitious materials on engineering properties of high strength concrete. Construction and Building Materials. 2011; 25(5):2639-2648. http://dx.doi.org/10.1016/j. conbuildmat.2010.12.013

8. Ribeiro DV, Labrincha JA and Morelli MR. Effect of calcined red mud addition on the hydration of portland cement. Materials Science Forum. 2012; 727-728:1408-1411. http:// dx.doi.org/10.4028/www.scientific.net/MSF.727-728.1408

9. Ribeiro DV, Labrincha JA and Morelli MR. Potential use of natural red mud as pozzolan for Portland cement. Materials Research. 2011; 14(1):60-66. http://dx.doi.org/10.1590/S151614392011005000001

10. Cordeiro GC, Toledo RD Fo and Fairbairn EMR. Effect of calcination temperature on the pozzolanic activity of sugar cane bagasse ash. Construction and Building Materials. 2009; 23(10):3301-3303. http://dx.doi.org/10.1016/j. conbuildmat.2009.02.013

11. Lima SA, Sales A, Moretti JP and Santos TJ. Análise de argamassas confeccionadas com a cinza do bagaço da 
cana-de-açúcar em substituição ao agregado miúdo. Revista Tecnológica. 2009; 18:87-97.

12. Frías M, Villar-Cocina E and Valencia-Morales E. Characterisation of sugar cane straw waste as pozzolanic material for construction: calcining temperature and kinetic parameters. Waste Management. 2007; 27(4):533-538. PMid:16714102. http://dx.doi.org/10.1016/j.wasman.2006.02.017

13. Nunes IHS, Vanderlei RD, Secchi M and Abe MAP. Estudo das características físicas e químicas do bagaço de cana-de-açúcar para uso na construção. Revista Tecnológica. 2009; (17):39-48.

14. Cook DJ, Pama RP and Paul BK. Rice husk ash-limecement mixes for use in masonry units. Building and Environment. 1977; 12(4):281-288. http://dx.doi. org/10.1016/0360-1323(77)90031-2
15. Yogananda MR and Jagadish KS. Pozzolanic properties of rice husk ash, burnt clay and red mud. Building and Environment. 1988; 23(4):303-308. http://dx.doi. org/10.1016/0360-1323(88)90036-4

16. Cordeiro GC, Toledo RD Fo and Fairbairn EMR. Characterization of sugar cane bagasse ash for use as pozzolan in cementitious materials. Quimica Nova. 2009; 32(1):82-86. http://dx.doi.org/10.1590/S0100-40422009000100016

17. Ribeiro DV, Labrincha JA, Silva AS and Morelli MR. Rheological properties and hydration behavior of Portland cement mortars containing calcined red mud. Canadian Journal of Civil Engineering. 2013; 40(6):557-566. http://dx.doi. org/10.1139/cjce-2012-0230 